Кузьменко Ганна Олександрівна аспірант кафедри публічного адміністрування, Міжрегіональна Академія управління персоналом, вул. Фрометівська, 2, м. Київ, 03039, тел.: (044) 490-95-00, e-mail: anna-kuzmenko96@ukr.net, https://orcid.org/0000-0003-0672-7633

\title{
СУЧАСНІ МЕХАНІЗМИ ФОРМУВАННЯ ТА ВИКОРИСТАННЯ ЛЮДСЬКОГО ПОТЕНЦАЛУ В СИСТЕМІ ДЕРЖАВНОГО УПРАВЛІННЯ
}

Анотація. Стаття присвячена дослідженню сучасних механізмам людського потенціалу в системі державного управління. Розкрита сутність інституціоналізації механізмів капіталізації людських ресурсів. Інститути конструктивного збалансування інтересів різних категорій населення та інституційні суб'єкти повинні стати інструментами для навчання та реалізації такої політики в системі державного управління.

Найважливішими аспектами забезпечення людського розвитку через освіту залишається забезпеченість на практиці виконання норм нового ЗУ «Про освіту» у задекларованих законодавцем нормах конституційного права на освіту через компоненти її безперервності, варіативності та якості.

Розширення правових меж регулювання права людини на освіту у новому Законі України «Про освіту» засвідчує те, що серед пріоритетів розбудови Української держави визначено чіткий напрям забезпечення людського розвитку через здійснення освітньої реформи та розробку на основі широкого громадського дискурсу і впровадження інноваційно зорієнтованої освітньої політики. Саме гарантії забезпечення права людини на освіту відображають інструментальний потенціал забезпечення людського розвитку через освіту (здійснення освітньої політики). Відповідно, не менш значущим чинником людського розвитку $\epsilon$ соціальна сфера, що забезпечує формування, збереження і збільшення людського потенціалу. Детермінуючий вплив i пріоритетність на розвиток людського потенціалу мають соціальні фактори. Наразі індекс розвитку людського потенціалу слугує показником для міжнародного порівняння і співставлення рівня i якості життя населення. Вирішення проблеми інвестування в розвиток «людського капіталу» дасть змогу досягнути не лише короткотермінового економічного успіху, а й закласти основу для формування позитивних довготермінових тенденцій в розвиток національної економіки з іiї подальшою інтеграцією в Свропейський Союз. Проблема інвестицій у людину особливо 
актуальна сьогодні, оскільки соціальна деформація в Україні набула масштабів, що загрожують економічній безпеці.

Ключові слова: людський потенціал, мінімізація ризиків, інститути, механізми інституціоналізації, система державного управління.

Kuzmenko Hanna Olexandrivna Postgraduated Student, Department of Public Administration, Interregional Academy of Personnel Management, Frometivska, 2, Kyiv, 03039, tel.: (044) 490-95-00, e-mail: anna-kuzmenko96@ukr.net, https://orcid.org/0000-0003-0672-7633

\section{MODERN MECHANISMS OF FORMATION AND USE OF HUMAN RESOURCES IN THE PUBLIC GOVERNANCE SYSTEM}

Abstract. The article is devoted to the study of modern mechanisms of human potential in the system of public administration. The institutionalization of mechanisms of capitalization of human resources is revealed. Institutions of constructive balancing of interests of different categories of the population and institutional subjects should become tools for training and realization of such policy in the system of public administration. The most important aspects of ensuring human development through education remain ensuring in practice the implementation of the new Law "On Education" in the norms of the constitutional right to education declared by the legislator through the components of its continuity, variability and quality.

Expanding the legal framework for regulating the human right to education in the new Law of Ukraine "On Education" shows that among the priorities of the Ukrainian state is a clear direction of human development through educational reform and development based on broad public discourse and implementation of innovationoriented educational policy. It is the guarantees of the human right to education that reflect the instrumental potential of ensuring human development through education (implementation of educational policy). Accordingly, no less important factor of human development is the social sphere, which ensures the formation, preservation and increase of human potential. Social factors have a determining influence and priority on the development of human potential. Currently, the Human Development Index serves as an indicator for international comparison and comparison of the level and quality of life of the population. Solving the problem of investing in the development of "human capital" will not only achieve short-term economic success, but also lay the foundation for the formation of positive long-term trends in the development of the national economy with its further integration into the European Union. The problem of investment in people is especially relevant today, as social deformation in Ukraine has become widespread, threatening economic security. 
Keywords: human potential, risk minimization, institutes, mechanisms of institutionalization, the system of public administration.

Постановка проблеми. На тлі постійної демографічної ситуації країни спостерігається зменшення кількісних параметрів подачі робочої сили та погіршення показників якості людського потенціалу в органах державного управління [9]. Зростання освіти та цін на здоров'я підвищує темп, оскільки зростання реального житла населення підриває інвестиційні перспективи розширення накопичення людського потенціалу та збільшує тенденцію до виконання його з підвищеними компетенціями, які не відповідають до сучасних рівнів в системі державного управління. За цих умов ризики людського потенціалу зростають: неможливість завершення та впровадження державних сфер знецінює інвестиції в освіту та професійне консалтинг, погіршує здоров'я задовго до виходу на пенсію, готує трудові міграційні землі та еміграцію призводить до довгострокового від'їзду від робочої сили, зосереджується на деструктивні та неформальні форми самореалізації [14].

Неможливість державних установ запобігти ескалації цих тенденцій свідчить про те, що їх не слід розглядати як спеціальні та достатні інституції для виправлення ситуації. Сучасне розуміння національної політики вимагає шляху державної реалізації людського потенціалу, щоб більше зосередитись на формуванні соціально-інституційних структур: конструктивне збалансування інтересів різних категорій суспільних інтересів, ефективна координація політичних рішень та реальних дій, представницька підтримка . I пряма адвокація щодо зацікавлених сторін між людьми між відповідними зацікавленими сторонами. Брати участь у розробці спільних проектах у державному управлінні та зменшувати ризики відчуження вигод від зростання людського капіталу.

Аналіз останніх досліджень і публікацій. Питання людського потенціалу почали розглядатися в теоріях людського розвитку, започаткованих інституціоналізмом в 70-80-х роках у працях Г. Беккера, М. Фрідмана, Т. Шульца, С. Фішера. В Україні методологічні питання розвитку, відтворення та використання людських ресурсів вивчали такі провідні вчені, як В. Антонюк, С. Бандур, Д. Богиня, В. Брич, О. Грішнова [2], М. Долішній, Я. Дерія , Т. Заяць, А. Колот, В. Куценко, О. Носик [10], Р. Яковенко [14], які зараз мають значне коло прихильників.

Мета статті полягає у дослідженні сучасних механізмів формування та використання людського потенціалу в системі державного управління.

Виклад основного матеріалу. Використання людського потенціалу в процесі державного управління та накопичення досвіду в боротьбі за кращу 
конкурентну позицію в розподілених результатах цієї діяльності дає можливість говорити про формування людського капіталу та його конверсії на його користь. Іншими словами, особливості людського капіталу, як сам капітал, не з'являються, коли людський потенціал практично використовує (наприклад, як основу для іноземного капіталу), але коли вони стають постійними для широкого розвитку людського потенціалу або соціального. Якщо не враховується, механічна ідентифікація людського потенціалу та людського капіталу підтримується для переоцінки людського капіталу населення України, отриманого на основі формальної освіти, але це не допомагає в пошуку відповідного ручного або подолання бідності , навіть працівників в різних сферах державного управління [2].

По суті, різниця між добре оплачуваним людським потенціалом та людським капіталом полягає у різниці між ступенем та ступенем участі людини у всьому спектрі державного регулювання відносин, розміром інституційних бар'єрів. Отже, зближення людського потенціалу та капіталу вимагає ерозії цих інституційних бар'єрів політичними засобами. Аналіз політики України показує, що ці інституційні цілі будуть досягнуті, якщо ця політика залишиться єдиною монополією державних структур [14]. Аналіз концептуальних підходів до державного регулювання установ діяльності тенденцій розвитку та тенденцій переробки, зарубіжний досвід підкреслює необхідність підготовки в Україні соціально інституційної системи ризику в галузі державного управління.

Замість монополії держави на організацію та регулювання ринку праці повинна існувати територіально-ієрархічна система публічних процедур для створення розширеного кола соціальних партнерів та консолідації законодавчих та нормативних актів. Основні параметри економічної діяльності населення; розширити галузь політики інституційного скорочення через працівника та безробітного населення, щоб зосередити увагу на найвищому потенціалі короткочасного та довгострокового постачання робочої сили; характер публічної політики від ризиків не тільки означають зосередження уваги на запобігання ризику, а й визначеного як важливою посиленого соціального діалогу. Теоретичною та методологічною основою пропонованих пріоритетів механізму управління інституційними ризиками у державній сфері є:

- законними інституційними утвореннями, в яких організація може розраховувати на достатній рівень відповідальності, $є$ не лише державні установи та органи виконавчої влади;

- законна інституціоналізації норм та стандартів взаємодії, але недостатньою для регулювання повсякденної практики та впровадження інституційних інновацій, не ставлячи під загрозу розвиток та людину [8].

Інституційний вплив діє за двома каналами, оскільки формується внутрішнє 
розуміння об'єкта своїх дій, а як зовнішня нормативна межа, яка характеризується специфічною подвійністю природи, що спричиняє інституційне регулювання, специфічною подвійністю. У той же час інституційне регулювання, в принципі, не використовує особисті правила або правила "про всяк випадок". В результаті цього інституційного регулювання непрямий вплив при створенні таких прикладів дій, правил та обмежень, які були зумовлені в основному незалежним об'єктом, який перетворюється з об'єкта управління в об'єкт взаємодії, перш ніж вибрати лінію поведінки, є бажаним траєкторія;

- інституційний механізм управління включає регулювання державними та недержавними суб'єктами, яке регулює здійснюється шляхом формування неформальних та імпліцитних інститутів, а також інституціоналізацією форм колективних дій та політичного процесу для встановлення процедур легітимації повноважень щодо створення нових правил;

- інституційний механізм є частиною соціального та правового механізму. Це спосіб встановити порядок, який стабілізує державну структуру і керує імітацією загальновизнаних норм поведінки. Коли фактори та умови господарської діяльності змінюються, постійно і постійно контролюється структура та рамки інституцій, а також правила, що їх реалізують, правила, угоди, контракти, угоди. Таким чином, інституційний механізм представляється особливим аспектом та способом здійснення процесу постійного створення та розвитку ефективної модифікації чи трансформації державних процесів. За своєю структурою цілісність забезпечується стабільними зв'язками окремих елементів, а структура характеризується: наявністю зв'язків між процесами формування, функціонування, корекції та реалізації інституційних обмежень в соціальному житті; часову послідовність їх здійснення; сукупність зворотного зв'язку, що має стабілізуючий ефект.

У рамках інституційного механізму доцільно визначити суб'єктів, інституційну структуру, що охоплює всю польову систему, структуру інституційних структур та комплексів, створених заздалегідь, а також державний механізм регулювання ринку праці та інші - регулювання, поєднання та взаємодія державних інституційних механізми утворюють складний інституційний механізм регулювання ринку праці.

Характерною особливістю інституціоналізації політики ризику у сфері людського потенціалу українського населення має стати акцент на зменшенні поляризації якісних показників економічної поведінки різних верств населення. Інституції, громадяни та інші соціальні суб'єкти повинні поступово відмовлятися від практики та свідомості делегування відповідальності та права створювати нові структури, шукати нові можливості та розвивати існуючі.

Повинна бути запроваджена нова свідомість та практика, згідно з якою 
головною функцією кожного члена суспільства є не споживання, а створення, включаючи нові робочі місця та нові можливості для людини. Серед безробітних переважна більшість не повинна шукати готову роботу, а намагатися відкрити власну справу. Серед мікропідприємств та індивідуальних підприємців слід наголосити на існуванні як дочірніх додатків середніх та великих підприємств, створених для соціально безвідповідальної оптимізації основних видів діяльності. Занадто багато власників підприємств та керівників шукають не шляхів конкуренції та перемоги в конкуренції, а способів вигадати державні преференції, заощадити на якісній роботі та найняти працівників.

Зниження соціального престижу в системі соціальних цінностей значною мірою пов'язані з низьким рівнем життя, досяжними та бажаними ознаками, смиренням, фаталізмом та залежним ставленням. Спотворені уявлення про сутність економічної діяльності та трудових відносин в ринкових умовах, застарілі погляди на роль i функції зайнятості призводять до підтримання пасивно-песимістичної моделі трудової поведінки. Слабка культура праці чітко асоціюється із слабкою культурою праці та дозвілля, остання завжди асоціюється 3 "нероботою", замість того, щоб орієнтуватися на відновлення та розвиток. Отже, нерозвиненість нематеріальних потреб змушує розвивати відповідні послуги, а також увагу до організації роботи в нетарифні, естетичні та ергономічні моменти. Перший заважає подальшому розвитку комерційних, соціальних та персональних послуг та їх якості, а другий - створенню та впровадженню конкурентоспроможної продукції на світовий ринок. Що потрібно для подолання цієї поляризації, розширення зайнятості та підвищення іiі якості в секторі послуг, вимагає не стільки зменшення зайнятості у так званому реальному секторі, скільки збільшення продуктивності праці. Однак, щоб забезпечити це зростання, амбітні, освічені та активні люди, пристосовані до високих естетичних стандартів продуктів та процесів, повинні прийти в реальний сектор, вимогливі до себе та якості навколишнього середовища.

Основними цілями та загальними результатами політичної роботи щодо стимулювання нової якісної професійної діяльності повинні бути збільшення зайнятості: зміцнення підприємництва; збільшення кількості робочих місць в зареєстрованих суб'єктах господарювання; активізація їх виходу на ринок праці та допомога в отриманні першої роботи після тривала перерва в досвіді роботи; активізація працевлаштування молоді, особливо в сільській місцевості, з гідною роботою; висока конкурентоспроможність та мобільність світової економіки та соціалізація зайнятості об’єктивно вимагають відповідної та швидкої інституціоналізації нових видів та форм зайнятості. Відповідно, існує потреба у державній підтримці розвитку аутсорсингу, домашньої роботи, законодавчої та регуляторної підтримки тристоронніх трудових відносин, таких як персонал та 
персонал, розширення використання строкових трудових договорів та неповної зайнятості. Однак принципом державної політики зайнятості в цьому напрямку має бути неминучість соціальної відповідальності та контролю за будь-якими нестандартними формами зайнятості, соціальна рівність їхніх індивідуальних та колективних трудових прав, що виключало б можливість погіршення умов праці та зайнятості гарантії фінансові, страхові та арбітражні зобов'язання.

Щоб державна політика могла забезпечити соціальний розвиток, вона не повинна бути прерогативою та завданням лише органів державної влади. Її внутрішній зміст та логіка вимагають активної участі у процесі всіх інституційних суб'єктів: територіальних та житлових громад, громадських організацій, профспілок та інших асоціацій працівників та самозайнятих осіб, організацій та асоціацій роботодавців, міжгалузевих та галузевих асоціацій тощо. Стимулювання цієї діяльності вимагає поєднання заходів державної допомоги та державного захисту свободи законодавчої ініціативи, розробки стандартів професій, кваліфікації, тарифів, умов праці, форм зайнятості, прогнозів тощо. А згодом радикальний огляд місця, мети та методів державного нагляду та статистичного моніторингу відповідності інституційних ініціатив та конкретних рішень вимогам Конституції України, спрощення судових процесів та розширення реальної доступності для приватних осіб та колективу прокурори. Політика зайнятості повинна забезпечувати загальну зайнятість та сприятливі умови праці, а також підтримувати конкретну зайнятість певних категорій людей, людей з інвалідністю та інших людей з інвалідністю, тих хто шукає першу роботу, та людей пенсійного та пенсійного віку, люди, які тривалий час не працювали на офіційних посадах, зневірились тощо. А також працевлаштування в шкідливих умовах, приховування травм, професійних захворювань, нелегальне працевлаштування, дискримінація, дитяча праця, штрафи, відрахування із заробітної плати та інші покарання, передбачені законодавством.

Доступна політика зайнятості повинна дотримуватися загальної фіскальної політики держави. Для цього останній слід зосередити увагу на пріоритеті доходу населення від зайнятості. 3 цією метою необхідно вирішити багато обов'язкових завдань Коригування заробітної плати підприємців 3 політикою стандартизації праці та умов праці, а також мистецтвом оподаткування та витрат на оплату праці для соціального страхування та доходів від праці. Зі стратегічної точки зору самі працівники повинні бути платниками податку на прибуток від праці та соціальними страховиками. Коли підрядниками фінансових та соціальних відносин, які складають фінансову та матеріальну основу соціальних та виробничих відносин, $є$ роботодавці, ні уряд, ні профспілки не захищатимуть інтереси робітників. При здійсненні трудових відносин неможливо розширити систему активізації діяльності органів місцевого самоврядування, громадських 
організацій, а також соціального страхування, без ефективного залучення працівників до уповноважених суб'єктів фінансово-бюджетного співробітництва. Основним пріоритетом першого кроку має бути мінімізація ризиків у сфері економічної діяльності населення. Основні пріоритети для інституціоналізації механізмів управління ризиками базуються на нашому розумінні складових ризику (ймовірність виникнення, розмір збитку (збитку) та значення ризику для суб'єкта господарювання) та відповідний розподіл механізмів на механізми для мінімізації ризику на індивідуальному рівні; механізми мінімізації негативного сприйняття ризику населення; механізми мінімізації збитків через негативні наслідки ризиків. Ми вважаємо, що система управління ризиками повинна мати сильний превентивний характер. Як результат, перший базовий рівень складається 3 механізмів мінімізації ризиків. Методи, пов’язані з запобіганням ризику, включаючи уникнення, зменшення ризику та підтримку ризику, $\epsilon$ ключовими.

Процедури прогнозування ризиків повинні бути інституціоналізованими. Сьогодні в Україні немає довгострокових прогнозів потреб у робочій силі, потреб у кваліфікації робітників, прогнозів ризиків на ринку праці, пов'язаних із світовими тенденціями, такими як оцифрування. Таким чином, у звіті Римського клубу за 2018 рік вказується, що майже половина існуючих робочих місць піддається високим ризикам автоматизації [7].

Управління сприйняттям ризику людського розвитку українським народом. Ставлення населення до ризиків за певних умов може зіграти вирішальну роль у збільшенні або зменшенні напруженості на ринку праці та в суспільстві в цілому. Це вимагає, зокрема, розробки призупинених інформаційних кампаній для покращення розуміння ситуації, що перебуває під загрозою, особливо коли існує ризик переоцінки. Як уже зазначалося, такі канали зв'язку, такі як соціальні мережі, мобільні додатки тощо, мають значний потенціал для цієї перспективи. Загальновідомо, що соціальні мережі в Інтернеті впливають на поведінку цих суб'єктів поза мережею i стають замаскованим елементом управління соціальними системами. Перевагами цього контролю $є$ ефективність досягнення мети, низькі фінансові витрати, можливість дистанційного управління свідомістю користувача в автоматизованому режимі та майже повні протоколи результатів. Управління ризиками у сфері державного регулювання людського потенціалу населення України в частині мінімізації негативного ризику.

Сприйняття ризиків повинно бути зосереджене на таких заходах: використання новітніх комунікаційних каналів та технологій для формування громадської думки щодо відповідності ризиків в державних органах; підвищення обізнаності громадськості про походження певних ризиків у громаді, про вже виниклі ризики, їх масштаби (кількісна оцінка), результати моніторингу та заходи 
щодо зменшення ризиків; підвищення ролі засобів масової інформації в інформуванні громадськості про реалізацію певних видів ризиків.

Удосконалення механізмів зменшення втрат від негативного впливу ризику у сфері економічної актуалізації людського потенціалу населення України $\epsilon$ важливим. Механізми цього рівня передбачають здійснення заходів після збитків i спрямовані на компенсацію наслідків страхування, захисту, обмеження, створення резервного фонду тощо. Основними пріоритетами їх інституціоналізації є: посилення ролі напівпрофілактичний вплив та заохочення запобігання ризикам соціально-трудові відносини; розподіл механізмів мінімізації збитків при нестандартних формах зайнятості [3].

Для оцінки сприйняття спільноти ризиків необхідно використовувати методи соціальних медіа, включаючи регулярні соціальні оцінки, щоб засвоїти соціальні норми для визнання відносин працівників щодо прийняття, ризику прийняття на ринку праці, адаптації до соціальних умов у цьому контексті . У той же час соціальні дослідження дозволяють дізнатись про унікальні соціальні характеристики та особливості працюючих людей до загальних характеристик життя та поведінки на ринку праці з точки зору цілей конкретного управління ризиками. Це має моделювати нинішній рівень або тенденції соціального ризику в конкретному ризику населення групи людей визначаються 3 урахуванням специфіки їх "життєвого потоку". 3 цією метою, на наш погляд, доречно взяти за основу методологічні підходи, розроблені МОП для вивчення переходу молоді від освіти до ринку праці (опитування SWTS) [11].

3 метою підвищення кваліфікації державних органів, які займаються або будуть займатися розробкою та реалізацією заходів щодо мінімізації ризиків, а також рівня підготовки представників державного і бізнес-сектора, ЗМI, які будуть задіяні обговорюючи актуальні питання, необхідно проводити спеціалізовані навчальні семінари). Пріоритети професійно-технічної освіти, а саме: - запровадження технології навчання та навчальних матеріалів, особливо комп'ютеризація та віртуалізація процесу набуття професійних знань та навичок. Прямі стажування використовують особливо перспективний напрямок у використанні технологій віртуальної реальності для підготовки високопродуктивних фахівців у державному управлінні. Це усуне один із недоліків сучасної системи освіти, який робить акцент майже на всіх роботодавцях - практична сторона набутих знань та відсутність практичних навичок. Вирішальний чинник у цьому розвитку є інновація, інвестує в людський капітал. Його тренування починається з гарної середньої освіти, і продовжує професійну освіту (включаючи сильну систему вищої освіти в галузі науки та техніки), оскільки загальна грамотність недостатня для прийняття деяких спеціальних знань та необхідних навичок, як правило, необхідно подолати нові 
технології. Нове завдання освіти - вивчити стратегії гнучкої поведінки на ринку праці, основи самоврядування на ринку праці. Оскільки пошук раціонального поєднання праці та відпочинку, а також перспективних видів діяльності, які можуть сформувати ефективний «робочий портфель», здатний збалансувати життя за різних умов життя, стає життєво важливим завданням кожної людини; номенклатура спеціальностей [13]. Система освіти повинна дивитись у майбутнє, зосереджуючись на професійних знаннях, які знадобляться в майбутньому. Тому спеціальності, пропоновані системою освіти, повинні регулярно переглядатися та оновлюватися. Для цього потрібно створити окремий орган, який міг би працювати під егідою певних об’єднань роботодавців або Міністерства освіти i науки - це не має значення. Місією такого закладу має бути довгостроковий прогноз ринку праці з урахуванням технологічної динаміки світової економіки та надання відповідних рекомендацій навчальним закладам;

- перетворення системи освіти загалом на державний заклад. Вже сьогодні цифрові технології дозволяють запроваджувати дистанційне навчання (точніше, електронне навчання), і ми можемо передбачити, що ця сфера освітніх послуг буде активно розвиватися в майбутньому. Перевагами цієї форми є гнучкість у розробці програми, вивчення дисциплін в індивідуальному темпі, можливість вибрати правильне місце та час для уроків. Легітимація дистанційного навчання полягає у розробці форм перевірки підсумкових знань та навичок, набутих в результаті навчання, які б гарантували незалежність у виконанні завдань, та сертифікації кваліфікації шляхом видачі сертифікатів певних знань та професійних компетентностей, які офіційно визнаний [13]. Досягнення такого компромісу в галузі освітніх послуг може створити офіційний механізм швидкої перепідготовки та відповідно забезпечити мобільність ринку праці. Легітимація дистанційного навчання полягає у розробці форм перевірки підсумкових знань та навичок, набутих в результаті навчання, які б гарантували незалежність у виконанні завдань, та сертифікації кваліфікації шляхом видачі сертифікатів певних знань та професійних компетентностей, які офіційно визнаний. Досягнення такого компромісу в галузі освітніх послуг може створити офіційний механізм швидкої перепідготовки та відповідно забезпечити мобільність ринку праці.

Висновки. Таким чином, зростаюча глобальна конкуренція за людський потенціал ставить під сумнів здатність забезпечити на національному рівні умови для його перетворення в людський капітал і його використання для людського розвитку в Україні.

Це вимагає переорієнтації державної політики на рівні міністрів на інклюзивну державну політику для боротьби з ризиками економічного оновлення людського потенціалу. Замість цього продовжуйте досліджувати і покращувати ті 
аспекти державної політики по боротьбі з ризиками для дисконтування людського потенціалу як механізми досягнення консенсусу в суспільстві, засоби реформування соціального діалогу та інститутів. Взаємодія державного та приватного секторів, методологічна та інформаційно-аналітична підтримка відповідних політики. Особливу увагу слід приділити вивченню світових практик, які в подальшому вийшли на рівень світових тенденцій, щоб запобігти можливі ризики і оперативно використовувати багатообіцяючий досвід.

\section{Лimepamypa:}

1. Андрияш В.И. Институционализация: понятие и содержание / В.И. Андрияш // Современные научные исследования и инновации.- 2014.- № 11 [Электронный pecypc]. URL: http://web.snauka.ru/issues/2014/11/39534

2. Грішнова О. А. Людський, інтелектуальний і соціальний капітал України: сутність, взаємозв'язок, оцінка, напрями розвитку / О. А. Грішнова // Соціально-трудові відносини: теоріята практика : зб. наук. пр. / М-во освіти і науки України, ДВНЗ «Київ. нац. екон. ун-т ім. Вадима Гетьмана» ; [редкол.: А. М. Колот (голова) та ін.]. - Київ : КНЕУ, 2014. - № 1. - С. 34-42.

3. Дерій Ж. В. Механізм державного регулювання системи відтворення людського потенціалу / Ж. В. Дерій // Інноваційна економіка. - 2012. - № 3 (29). - С. 279-285.

4. Дерій Ж.В. Капіталізація людського потенціалу: теорія, методологія, практика : монографія / Ж. В. Дерій. - Чернігів: Черніг. нац. технол. ун-т, 2013. - 300 с.

5. Інноваційна Україна 2020: національна доповідь / за заг. ред. В.М. Гейця та ін. ; НАН України.-К., 2015. -336с.

6. Капелюшников, Р. И. Трансформация человеческого капитала в российском обществе (на базе «Российского мониторинга экономического положения и здоровья населения») / Р. И. Капелюшников, А. Л. Лукьянова. - Москва: Фонд «Либеральная миссия», 2010. - 196 с

7. Людський розвиток в Україні: інституційне підгрунтя соціальної відповідальності : кол. моногр. / за ред. Е.М. Лібанової; відпов. за випуск О.В. Макарова, О.М. Хмелевська; Ін-т демографії та соціальних досліджень імені М.В. Птухи НАН України. - Київ, 2017. - 368

8. Мельничук Д.П. Людський капітал: пріоритети модернізації суспільства у контексті поліпшення якості життя населення : монографія / Д.П. Мельничук. - Житомир: Полісся, 2015. - 564 с.

9. Населення України. Імперативи демографічного старіння. - К.: ВД «АДЕФУкраїна», 2014. - 288 с.

10. Носик О.M. Деструктивні трансформації людського капіталу в Україні: інвестиційний аспект // Бізнес Інформ. — 2015. — № 7 (450);

11. Перехід на ринок праці молоді України: результати міжнародного дослідження «School-to-work transition surveys» в Україні у 2013 та 2015 роках /Елла Лібанова, Олександр Цимбал, Олег Ярош та Лариса Лісогор ; Міжнародне бюро праці. - Женева : МОП, 2016.

12. Стан виконання в Україні положень «Порядку денного на XXI століття» (20022012) / За ред. Руденко Л.Г. - К. : Академперіодика,2014. - 359 с.

13. Українське суспільство: міграційний вимір : нац. доповідь / Інститут демографії та соціальних досліджень ім.М. В. Птухи НАН України.-К.,2018. - 396 с.

14. Яковенко, Р. В. Людський капітал та людський потенціал / Р. В. Яковенко // Наукові праці Кіровоградського національного технічного університету. Економічні науки: зб. наук. пр. - Кіровоград: КНТУ, 2013. - Вип. 24. - С. 186-193. 
15. Cummins, J. D. Convergence of Insurance and Financial Markets: Hybrid and Securitized Risk- Transfer Solutions [Текст] / J. David Cummins, Mary A. Weiss // The Journal of Risk and Insurance. - 2009. - № 3. - C. 493-545.

16. Fernández, Almudena; López-Calva, Luis F. (2010). "Transitory Shocks, Permanent Effects: Impact of The Economic Crisis on the Well-Being of Households in Latin America and the Caribbean" (PDF). Estudios Económicos. 25 (1): 3-35. Retrieved 2012-03-25.

17. Holzmann, Robert \& Jorgensen, Steen. (2001). Social Risk Management: A New Conceptual Framework for Social Protection. International Tax and Public Finance. 8. 529-556.

18. Holzmann, Robert; Lynne Sherburne-Benz; Emil Tesliuc (May 2003). "Social Risk Management:The World Bank Approach to Social Protection in a Globalizing World" (PDF). World Bank. Retrieved April 6, 2014.

19. Holzmann, Robert; Steen Jorgensen (2000). "Social Risk Management: A new conceptual framework for Social Protection, and beyond" (PDF). World Bank. Retrieved November 21, 2006.

20. The Global Human Capital Report 2017. World economic forum [Electronic recourse]. Available at : http:// https://weforum.ent.box.com/s/dari4dktg4jt2g9xo2

21. Tolbert P. The Instytutionalization of Institutional Theory/ P. Tolbert., L. Zucker // S. Clegg. - 1996. - S. 182.

\section{References:}

1. Andriiash, V.I. (2014). Institutcionalizatciia: poniatie i soderzhanie [Institutionalization: concept and content]. Sovremennye nauchnye issledovaniia i innovatcii - Modern scientific research and innovations, 11 (3). Retrieved from http://web.snauka.ru/issues/2014/11/39534 [in Russian].

2. Hrishnova, O.A. (2014). Liudskyi, intelektualnyi i sotsialnyi kapital Ukrainy: sutnist, vzaiemozviazok, otsinka, napriamy rozvytku [Human, intellectual and social capital of Ukraine: essence, relationship, evaluation, directions of development]. Sotsialno-trudovi vidnosyny: teoriia ta praktyka - Social and labor relations: theory and practice, 1, 34-42 [in Ukrainian].

3. Derii, Zh.V. (2012). Mekhanizm derzhavnoho rehuliuvannia systemy vidtvorennia liudskoho potentsialu [The mechanism of state regulation of the system of reproduction of human potential]. Innovatsiina ekonomika - Innovative economy, 3(29), 279-285 [in Ukrainian].

4. Derii, Zh.V. (2013). Kapitalizatsiia liudskoho potentsialu: teoriia, metodolohiia, praktyka [Capitalization of human potential: theory, methodology, practice]. Chernihiv: Chernih. nats. tekhnol. un-t [in Ukrainian].

5. Heiets, V.M., et al. (2015). Innovatsiina Ukraina 2020: natsionalna dopovid [Innovative Ukraine 2020: national report]. Kyiv: NAN Ukrainy [in Ukrainian].

6. Kapeliushnikov, R.I. Lukianova, A.L. (2010). Transformatciia chelovecheskogo kapitala $v$ rossiiskom obshchestve (na baze «Rossiiskogo monitoringa ekonomicheskogo polozheniia $i$ zdorovia naseleniia») [Transformation of human capital in Russian society (based on the "Russian monitoring of the economic situation and health of the population")]. Moscow: Fond «Liberalnaia missiia» [in Russian].

7. Makarova, O.V., Khmelevska, O.M. (2017). Liudskyi rozvytok v Ukraini: instytutsiine pidgruntia sotsialnoi vidpovidalnosti [Human development in Ukraine: the institutional basis of social responsibility]. E.M. Libanova (Eds.). Kyiv: In-t demohrafii ta sotsialnykh doslidzhen imeni M.V. Ptukhy NAN Ukrainy [in Ukrainian].

8. Melnychuk, D.P. (2015). Liudskyi kapital: priorytety modernizatsii suspilstva u konteksti polipshennia yakosti zhyttia naselennia [Human capital: priorities of society modernization in 
the context of improving the quality of life of the population]. Zhytomyr: Polissia [in Ukrainian].

9. Naselennia Ukrainy. Imperatyvy demohrafichnoho starinnia [Population of Ukraine. Imperatives of demographic aging]. (2014). Kyiv: VD «ADEF-Ukraina» [in Ukrainian].

10. Nosyk, O.M. (2015). Destruktyvni transformatsii liudskoho kapitalu v Ukraini: investytsiinyi aspekt [Destructive transformations of human capital in Ukraine: investment aspect]. Biznes Inform - Business Inform, 7(450), 113-118 [in Ukrainian].

11. Libanova, E., Tsymbal, O., Yarosh O., Lisohor, L. (2016). Perekhid na rynok pratsi molodi Ukrainy: rezultaty mizhnarodnoho doslidzhennia «School-to-work transition surveys» $v$ Ukraini $u$ 2013 ta 2015 rokakh [Transition to the youth labor market of Ukraine: the results of the international study "School-to-work transition surveys" in Ukraine in 2013 and 2015]. Zheneva: MOP [in Ukrainian].

12. Rudenko, L.H. (Eds.). (2014). Stan vykonannia v Ukraini polozhen "Poriadku dennoho na KhKhI stolittia» (2002-2012) [Status of implementation in Ukraine of the provisions of the "Agenda for the XXI century" (2002-2012)]. Kyiv: Akademperiodyka [in Ukrainian].

13. Ukrainske suspilstvo: mihratsiinyi vymir : nats. Dopovid [Ukrainian society: the migration dimension: national report]. (2018). Kyiv: Instytut demohrafii ta sotsialnykh doslidzhen im. M. V. Ptukhy NAN Ukrainy [in Ukrainian].

14. Yakovenko, R.V. (2013). Liudskyi kapital ta liudskyi potentsial [Human capital and human potential]. Naukovi pratsi Kirovohradskoho natsionalnoho tekhnichnoho universytetu. Ekonomichni nauky - Scientific works of Kirovograd National Technical University. Economic sciences, 24, 186-193 [in Ukrainian].

15. Cummins, J.D., Weiss, M.A. (2009). Convergence of Insurance and Financial Markets: Hybrid and Securitized Risk-Transfer Solutions. The Journal of Risk and Insurance, 3, 493-545 [in English].

16. Fernández, A., López-Calva, L.F. (2010). Transitory Shocks, Permanent Effects: Impact of The Economic Crisis on the Well-Being of Households in Latin America and the Caribbean. Estudios Económicos, 25(1), 3-35 [in English].

17. Holzmann, R., Jorgensen, S. (2001). Social Risk Management: A New Conceptual Framework for Social Protection. International Tax and Public Finance, 8, $529-556$ [in English].

18. Holzmann, R., Sherburne-Benz, L., Tesliuc, E. (2003). Social Risk Management: The World Bank Approach to Social Protection in a Globalizing World. Washington, D.C. [in English].

19. Holzmann, R., Steen, J. (2000). Social Risk Management: A new conceptual framework for Social Protection, and beyond. International Tax and Public Finance, 8(4), 529-556 [in English].

20. The Global Human Capital Report 2017. (2017). www.weforum.org. Retrieved from https://www.weforum.org/reports/the-global-human-capital-report-2017 [in English].

21. Tolbert, P. S. \& Zucker, L. G. (1996). The institutionalization of institutional theory. S.Clegg, C. Hardy and W. Nord (Eds.). Handbook of organization studies. (pp. 175-190). London: SAGE [in English]. 